\title{
Role of the NLRP3 inflammasome in the transient release of IL-1 $\beta$ induced by monosodium urate crystals in human fibroblast-like synoviocytes
}

\author{
Shu-cong Zheng ${ }^{1,2+}$, Xiao-xia Zhu ${ }^{1,2 \dagger}$, Yu Xue ${ }^{1,2}$, Li-hong Zhang ${ }^{3}$, He-jian Zou ${ }^{1,2}$, Jian-hua Qiu ${ }^{2,4^{*}}$ \\ and Qiong Liu 2,3, $^{*}$
}

\begin{abstract}
Background: To investigate whether monosodium urate (MSU) crystals induce interleukin (IL)-1 $\beta$ in human fibroblast-like synoviocytes (FLS), and whether the NLRP3 inflammasome is involved in the inflammatory mechanism.

Methods: Human FLS isolated from explants of synovial tissue were stimulated with MSU crystals ( 0.001 to $0.5 \mathrm{mg} / \mathrm{ml}$ ) for different time course ( 6 hours to 48 hours). The expressions of IL-1 $\beta$, IL-6, TNF- $a$ and NLRP3 were evaluated with ELISA, Western blot and quantitative real-time PCR.

Results: Exposure of FLS to MSU crystals transiently induced a significant increase in IL-1 $\beta$ expression in culture medium with a peak at $6 \mathrm{~h}$. The mRNA level of IL-1 $\beta$ in the FLS cells had a similar pattern at this time point. Changes in IL-6 and TNF-a expression were not observed. Simultaneously, intercellular pro-IL-1 $\beta$ was detected at $6 \mathrm{~h}$. Furthermore, MSU crystals also induced NLRP3 mRNA and protein expression at $6 \mathrm{~h}$ to $48 \mathrm{~h}$ after MSU treatment.
\end{abstract}

Conclusions: MSU crystals directly increased IL-1 $\beta$ and intercellular NLRP3 expression in FLS cells. It is suggested that the NLRP3 inflammasome may be associated with IL-1 in FLS treated with MSU. Altogether, MSU could induce production and release of IL-1 $1 \beta$ through the NLRP3 inflammasome in human synoviocytes.

Keywords: MSU, NLRP3, Inflammasome, IL-1 $\beta$, Synoviocytes

\section{Background}

Gout is one of inflammatory arthritis due to deposition of monosodium urate (MSU) crystals in synovial fluid and joints [1]. As demonstrated in vivo, MSU crystals cause inflammation. When MSU crystals were injected into the peritoneum in an animal model of acute gout, it induced the production of proinflammatory cytokines such as interleukin-1 $\beta$ (IL-1 $\beta)$ [2].

Although MSU is identified as a causative agent in gout $[3,4]$, the mechanisms underlying MSU crystalinduced inflammation have only recently begun to be understood [3,5]. Pro-inflammatory cytokines play a critical role in the inflammatory reaction induced by

\footnotetext{
* Correspondence: jianhua.qiu@childrens.harvard.edu; liuqiong@fudan.edu.cn ${ }^{\dagger}$ Equal contributors

${ }^{2}$ Institute of Rheumatology, Immunology and Allergy, Fudan University, Shanghai, China

${ }^{3}$ Department of Anatomy, Histology and Embryology, Shanghai Medical College of Fudan University, 138 Yixueyuan Road, Shanghai 200032, PR China Full list of author information is available at the end of the article
}

MSU-crystals [6,7]. It is suggested by several studies that IL-1 $\beta$, the pathological hallmark of the acute inflammatory attack, is a key regulatory pro-inflammatory cytokine in gout, which promotes a neutrophil influx into the synovium and joint fluid $[8,9]$. Moreover, IL-1 $\beta$ also plays a crucial role in driving the transition from the acute phase of arthritis to the chronic irreversible phase [10].

IL-1 $\beta$-dependent inflammation, occurring in a number of diseases in addition to gout, depends on the MSU-induced formation of a macromolecular nucleotide-binding domainlike receptor protein 3 (NLRP3) inflammasome complex [3,11-13]. The NLRP3 (also known as NALP3) inflammasome has been shown to form through homotypic interactions between the CARD and PYD domains of NLRP3, Pyrin and apoptosis-associated speck like protein (ASC). After the NLRP3 inflammasome is formed, it converts procaspase- 1 to active caspase- 1 , which in turn cleaves pro-IL-1 $\beta$ to active IL-1 $\beta$. Although MSU has been described as a causative agent in gout for more than 100 
years [14], its mechanism of action was not understood until the discovery of NLRP3 a decade ago [15].

Accumulating evidence suggests that MSU crystalinduced inflammation has undergone phagocytosisactivated the NLRP3 inflammasome, which leads to secretion of IL-1 $\beta$ from resident macrophages [16-18]. In turn, this secretion can increase the production of IL-1 $\beta$ and other inflammatory mediators further, and promote the activation of synovial lining cells and phagocytes $[3,19]$. Recent studies show that MSU crystals induce synoviocytes to release CCL2 (monocyte chemoattractant protein-1; MCP-1) and recruit monocytes/macrophages to joints [20]. However, it is unclear whether MSU causes synoviocytes to produce IL- $1 \beta$, and if so, what the potential mechanisms are. The aim of the present study is to address whether synoviocytes can activate transcriptional levels of IL-1 $\beta$, and secrete IL-1 $\beta$ after exposure to MSU crystals. An additional aim is to explore the potential underlying molecular mechanisms.

\section{Materials}

\section{FLS isolation and culture}

The study was approved by the Ethics Committees of Huashan Hospital, Fudan University. Synovial tissues were obtained from one patient, who had joint replacement due to idiopathic femoral head necrosis. Synovial fibroblasts were isolated from the synovial tissues by enzymatic digestion. FLS were isolated from tissue explants, as previously described [21]. In brief, synovium tissues were rinsed several times in PBS, minced into 1-mm pieces, placed in T25 flasks (Falcon, USA), and maintained in DMEM supplemented with $10 \%$ heatinactivated fetal calf serum (FCS), $50 \mu \mathrm{g} / \mathrm{ml}$ streptomycin, $50 \mathrm{U} / \mathrm{ml}$ penicillin, and $2 \mathrm{mmol} / \mathrm{L}$ glutamine (10\% FCS medium). At confluence, cells were harvested (trypsin/EDTA) and seeded into new flasks. All experiments were carried out with passage 4 through 8 FLS.

\section{Reagents}

MSU crystals were purchased from Alexis (Enzo Life Sciences, USA). Cell culture reagents including media, phosphate buffered saline (PBS), and Hank's balanced salts solution (HBSS), penicillin-streptomycin, glutamax, and fetal calf serum (FCS) were obtained from Invitrogen (USA). Polyclonal anti-pro-IL-1 $\beta$, anti-NLRP3 antibody was purchased from Santa Cruz Biotechnology (Santa Cruz, USA).

\section{Cytokine detection by ELISA}

FLS were plated at $2.0 \times 10^{4}$ cells/well in a 24-well plate. When they reached subconfluency, the medium was removed, and fresh medium was applied along with MSU $(1,10,50,100,200,500 \mathrm{ug} / \mathrm{ml})$. The supernatants were collected after stimulation with MSU for 6 h, 12 h, $24 \mathrm{~h}$ and $48 \mathrm{~h}$ respectively. IL-1 $\beta$, IL-6, and TNF $\alpha$ levels in the supernatants were measured by ELISA (R\&D Systems, USA) according to the manufacturer's protocol.

\section{Quantitative real-time PCR}

Total RNA was extracted using RNA Lyzol reagent (EXcell Bio, Shanghai, China). cDNA was synthesized with the Rever TraAceHqPCR RT Kit (TOYOBO. CO, TLD, Japan). Quantitative real-time PCR was performed on a 7500 Fast Real-Time PCR System (AB Applied Biosystems, USA) using SYBRH Green Realtime PCR Master Mix (TOYOBO. CO, TLD, Japan). The specificity of amplification was assessed for each sample by melting curve analysis. Relative quantification was performed using standard curve analysis. The quantification data are presented as a ratio to the control level. The Homo sapiens (hs) gene specific primers used were as follows: IL-1 $\beta, 5^{\prime}$-TTGTTG CTCCATATCCTGTCC-3' (forward) and 5'-CACATGGG ATAACGAGGCTT-3' (reverse); IL-6, 5' -GGAGACTTGC CTGGTGAA-3' (forward) and 5'-GCATTTGTGGTTG GGTCA-3' (reverse); TNF $\alpha, 5^{\prime}$-CACTAAGAATTCAAA CTGGGGC-3' (forward) and 5' - GAGGAAGGCCTAA GGTCCAC-3' (reverse); NLRP3, 5'-TAAAGAGATGAGC CGAAGTGGG-3' (forward) and 5'-TCAATGCTGTCT TCCTGGCA-3' (reverse); GAPDH, 5'-ATGACCCCTTC ATTGACC-3' (forward) and antisense 5'-GAAGATGGT GATGGGATTTC-3' (reverse).

\section{Western blot analysis}

FLS were seeded in 6-well culture plates at a density of 1 $\times 10^{6}$ cells/well. The cells were allowed to adhere for 24 hours, and then the cells were cultured in the medium with $2 \%$ FCS and $50 \mu \mathrm{g} / \mathrm{ml}$ MSU crystals for 6 hours or 48 hours. The cells were disrupted in lysis buffer $(20 \mathrm{mM}$ Tris, $\mathrm{pH}$ 7.5, $150 \mathrm{mM} \mathrm{NaCl}, 1 \mathrm{mM}$ EDTA, $1 \mathrm{mM}$ EGTA, 1\% Triton X-100, $2.5 \mathrm{mM}$ sodium pyrophosphate, and $1 \mathrm{mM}$ b-glycerophosphate) with $1 \mathrm{mM}$ PMSF, $1 \mathrm{mg} / \mathrm{ml}$ leupeptin, and $1 \mathrm{mM}$ sodium orthovanadate (Sigma, USA). The concentrations of the extracted proteins were measured using a BCA Protein Assay Kit (Thermo Fisher Scientific, USA). Samples $(50 \mu \mathrm{g}$ of total protein) were dissolved with equal volume of loading buffer (0.1 M Tris- $\mathrm{HCl}$ buffer ( $\mathrm{pH}$ 6.8) containing $0.2 \mathrm{M} \mathrm{DTT}, 4 \%$ SDS, $20 \%$ glycerol and $0.1 \%$ bromophenol blue), separated on 10\% SDS-PAGE and then electrotransferred at $100 \mathrm{~V}$ to Immun-Blot PVDF membrane for 1 hour at $4^{\circ} \mathrm{C}$. Membranes were blocked in TBST containing $5 \%$ non-fat milk overnight at $4^{\circ} \mathrm{C}$ before incubation for $2 \mathrm{~h}$ at room temperature with primary antibodies diluted in TBST containing 5\% BSA. Blots were washed extensively in TBST and incubated with secondary antibodies in TBST/1.25\% BSA for $1 \mathrm{~h}$ at room temperature. The signal was detected by an enhanced chemiluminescence method (ECL kit, Amersham), and exposed to Kodak X-OMAT film (Eastman Kodak, Rochester, 
NY, U.S.A.). The intensity of the selected bands was captured and analyzed using GeneSnap Image Analysis Software (Syngene, U.K.). We used rabbit polyclonal anti-human NLRP3 antibody (Santa Cruz Biotechnology, Santa Cruz, CA, USA), anti-human pro-IL1- $\beta$ (Santa Cruz Biotechnology, Santa Cruz, CA, USA) and rabbit polyclonal anti-human GAPDH antibody (Cell Signaling, Danvers, MA) as primaryantibodyand anti-rabbitIgG HRP-linked antibody (CellSignaling,USA) as secondaryantibody.

Data analysis

Data are presented as mean \pm S.E.M. and analyzed by SPSS 11.0. Repeated measures analysis of variance (ANOVA) followed by S-N-K test were used for post-hoc analysis of differences between groups. $\mathrm{P}<0.05$ was considered a statistically significant difference.

\section{Results}

Effects of MSU on the release of proinflammatory cytokines IL-1 $\beta$, TNFa and IL- 6 from FLS

We first compared IL-1 $\beta$, TNF $\alpha$ and IL-6 levels at different time points in the culture media after FLS cells were exposed to different concentrations of MSU crystals. The levels of IL-1 $\beta$, TNF- $\alpha$ and IL- 6 triggered by $1 \mathrm{ug} / \mathrm{ml}$, $10 \mathrm{ug} / \mathrm{ml}, 50 \mathrm{ug} / \mathrm{ml}, 100 \mathrm{ug} / \mathrm{ml}, 250 \mathrm{ug} / \mathrm{ml}$ and $500 \mathrm{ug} / \mathrm{ml}$ of MSU at $6 \mathrm{~h}, 12 \mathrm{~h}, 24 \mathrm{~h}$ and $48 \mathrm{~h}$ respectively are
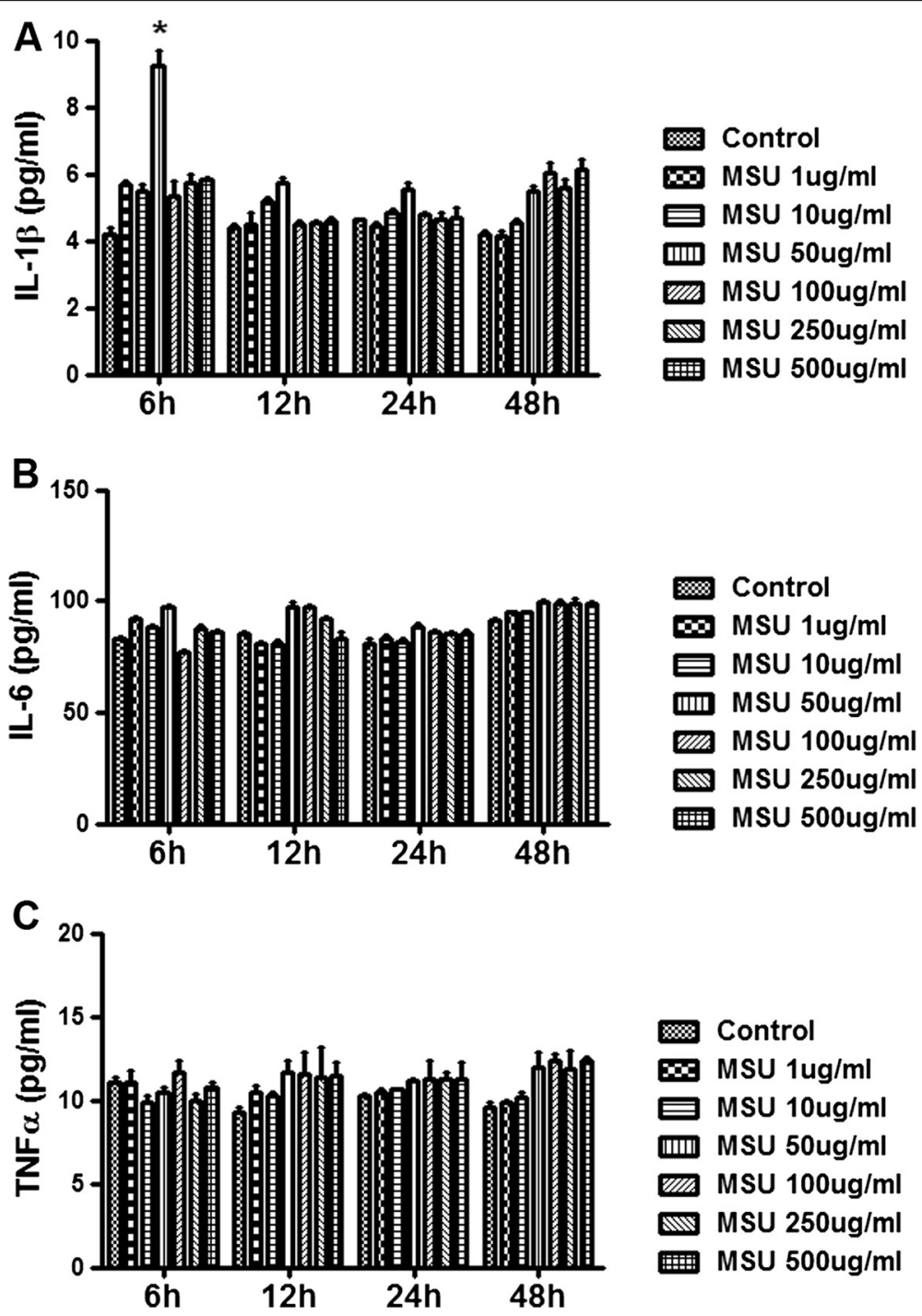

Figure $1 \mathrm{MSU}$ induced IL-1 $\beta$ production in FLS. FLS were stimulated with $1 \mathrm{ug} / \mathrm{ml}, 10 \mathrm{ug} / \mathrm{ml}, 50 \mathrm{ug} / \mathrm{ml}, 100 \mathrm{ug} / \mathrm{ml}, 250 \mathrm{ug} / \mathrm{ml} \mathrm{and} 500 \mathrm{ug} / \mathrm{ml}$ of MSU at $6 \mathrm{~h}, 12 \mathrm{~h}, 24 \mathrm{~h}$ and $48 \mathrm{~h}$ respectively. The control group is treated with PBS, which is used to dilute different dosage of MSU. Supernatants were collected for IL-1 $\beta$, TNF-a and IL-6 protein detection by ELISA. The concentration of MSU $50 \mathrm{ug} / \mathrm{ml}$ induced the significant increase of IL-1 $\beta$ in the supernatants collected after 6 hours MSU exposure $(\mathbf{A}, p<0.05)$. There is no significant difference for the levels of IL-6 (B) and TNF- $a$ (C) in the supernatant of FLS exposed to different concentration MSU at the four time courses. Data presented are mean \pm S.E.M. * *epresents $P<0.05$ in comparison with control during statistical analysis. 
shown in Figure 1. The results indicated that $50 \mathrm{ug} / \mathrm{ml}$ of MSU induced a significant increase in IL-1 $\beta$ after 6 hours, but not at other time points (Figure 1A). The result was re-confirmed by using serial MSU concentrations close to $50 \mathrm{ug} / \mathrm{ml}$ (Additional file 1: Figure S1). Furthermore, there were no significant differences in levels of IL-6 (Figure 1B) and TNF $\alpha$ (Figure 1C) in FLS exposed to different concentrations of MSU at all exposure periods.

\section{IL-1 $\beta$, TNFa and IL- 6 mRNA expression in MSU treated FLS} The mRNA levels of IL- $1 \beta$, TNF- $\alpha$ and IL- 6 in FLS treated with different doses of MSU were measured with Q-PCR at two representative time points, short-term $6 \mathrm{~h}$ and long-term $48 \mathrm{~h}$. As shown in Figure 2A, $50 \mathrm{ug} / \mathrm{ml}$ of MSU induced a 3 to 4 -fold increase in IL- $1 \beta$ mRNA expression $6 \mathrm{~h}$ after treatment (Figure $2 \mathrm{~A}, \mathrm{p}<0.05$ ), compared to the control group. There was no significant change in mRNA levels of TNF- $\alpha$ and IL- 6 at this time point. At the $48 \mathrm{~h}$ time point, different doses of MSU did not alter mRNA levels of IL-1 $1 \beta$, TNF- $\alpha$ or IL- 6 (Figure 2B).

\section{MSU mediated the consumption of storage pro-IL-1 $\beta$ at the $6 \mathrm{~h}$ time point in the FLS}

Western blot analysis showed that MSU induced pro-IL-1 $\beta$ expression in FLS treated with different doses of MSU (Figure 3). A single band of the expected size $(\sim 31 \mathrm{kDa})$ for pro-IL-1 $\beta$ was detected by the specific primary antibody (Figure 3A). The increase in levels of pro-IL-1 $\beta$ protein was significant after $50 \mathrm{ug} / \mathrm{ml}$ of MSU treatment compared to the control group (Figure 3B; $\mathrm{p}<0.05$ ). Also as shown in Figure $3 \mathrm{~B}$, the other doses of MSU had no effect on pro-IL-1 $\beta$ protein expression at the $6 \mathrm{~h}$ time point. At the
$48 \mathrm{~h}$ time point, pro-IL-1 $\beta$ protein expression was undetectab. in all groups (data not shown).

\section{Effect of MSU on NLRP3 expression in FLS}

NLPR3 protein level was significantly increased following treatment with different doses of MSU at the $6 \mathrm{~h}$ time point (Figure 4A; $\mathrm{p}<0.05)$. The band of NLPR3 was detected by immunoblot (Figure 4B). In addition, no band was observed when the primary antibody was omitted (data not shown). Similar changes were observed at $48 \mathrm{~h}$. At this time point NLPR3 protein level was dramatically increased after exposure to MSU (Figure 4C; $<<0.05$ and $\mathrm{p}<0.01$ ) and the band of NLRP3 could still be detected (Figure 4D). According to the Q-PCR analysis, NLPR3 mRNA level was markedly increased in the FLS at 6 hours after exposure to different doses of MSU (Figure 4E; $\mathrm{p}<0.05$ and $\mathrm{p}<0.01$ ). Similarly, a significant increase in NLPR3 mRNA level was also seen at $48 \mathrm{~h}$ (Figure 4F; $\mathrm{p}<0.05, \mathrm{p}<0.01$ and $\mathrm{p}<0.001$ ).

\section{Discussion}

It is well-known that neutrophils and macrophages are involved in the inflammatory reaction in gout [19,22-24]. In addition, the role of inflammasomes in the development of a number of diseases including gout, has been demonstrated in these cells $[17,23,25]$. However, due to complex interactions among various cell types, including neutrophils, macrophages, mast cells, endothelial cells and synovial fibroblasts $[26,27]$, it is possible that synovial fibroblasts also may play a role in modulating the inflammatory response to MSU crystals in gout. In this study, we addressed the role of synovial fibroblasts in mediating the release of mature IL- $1 \beta$ via activation of the NLRP3 inflammasome after exposure to MSU. We observed that MSU increased the release of IL-1 $\beta$, but not IL- 6 and TNF-a, in the supernatants of MSU-treated
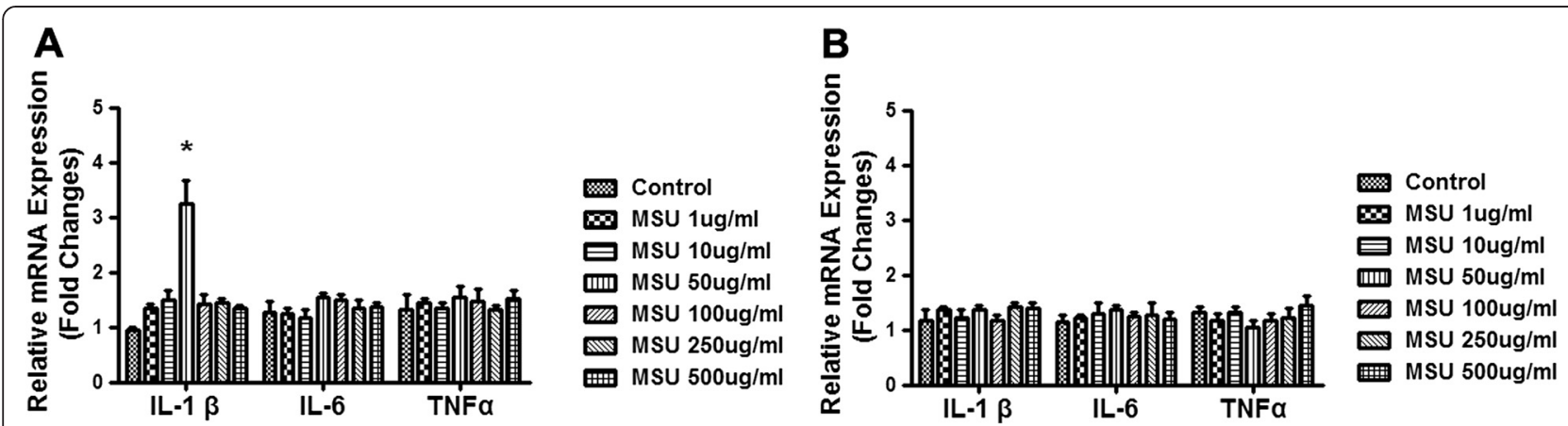

Figure 2 MSU induced IL-1 $\beta$ mRNA expression in FLS. FLS were stimulated with $1 \mathrm{ug} / \mathrm{ml}, 10 \mathrm{ug} / \mathrm{ml}, 50 \mathrm{ug} / \mathrm{ml}, 100 \mathrm{ug} / \mathrm{ml}, 250 \mathrm{ug} / \mathrm{ml}$ and $500 \mathrm{ug} / \mathrm{ml}$ of MSU at short-term time point $6 \mathrm{~h}$ and long-term time point $48 \mathrm{~h}$ respectively. Cells were collected for IL-1 $\beta$, TNF- $\alpha$ and IL- $6 \mathrm{mRNA}$ detection by Q-PCR. The concentration of MSU $50 \mathrm{ug} / \mathrm{ml}$ induced the significant increase of IL-1 $\beta$ mRNA expression in the cells collected after 6 hours MSU exposure $(\mathbf{A}, \mathrm{p}<0.05)$. There was no significant difference for the levels of IL-6 and TNF-a mRNA expression in the cells of FLS exposed to different concentration MSU whether at the $6 \mathrm{~h}$ time point or the $48 \mathrm{~h}$ time point. (B) Data were three independent experiments and presented are mean \pm S.E.M. * ${ }^{*}$ represents $\mathrm{P}<0.05$ in comparison with control during statistical analysis. 


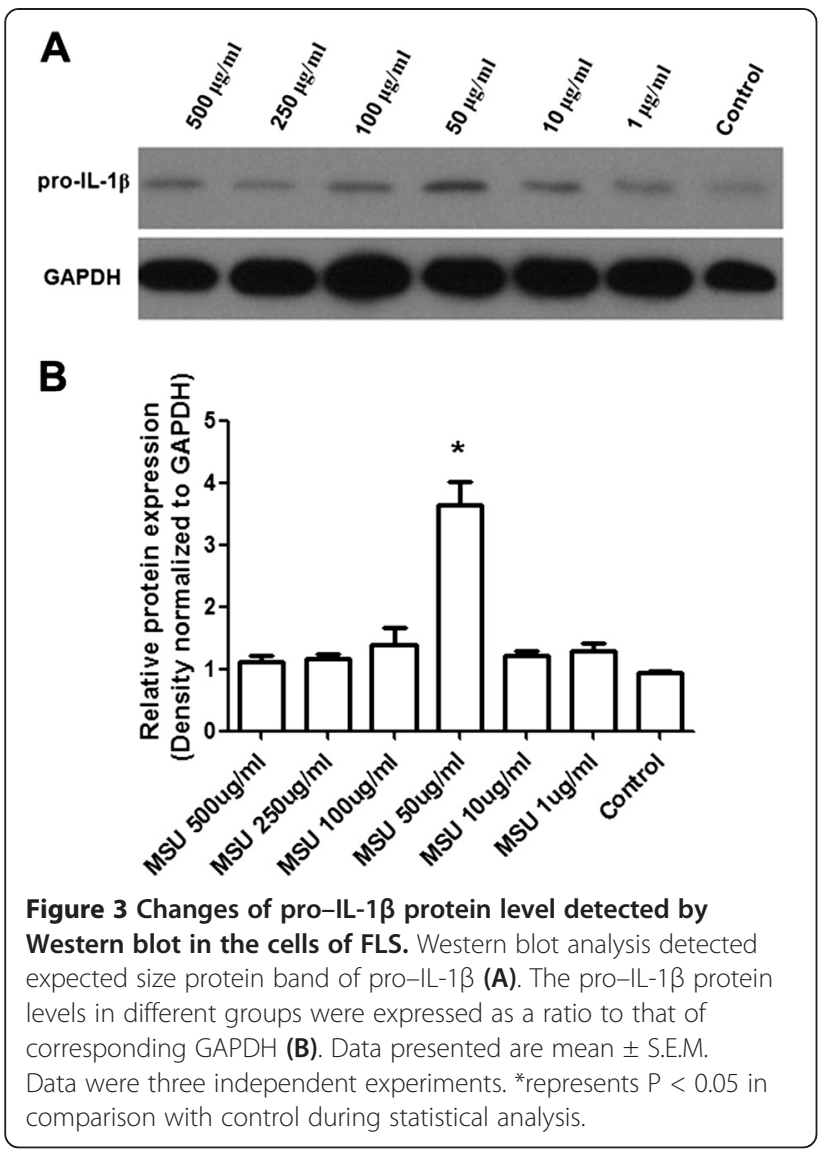

FLS. Low concentrations of MSU transiently triggered an increase in mRNA and protein levels of IL-1 $\beta$ in FLS. Moreover, the formation of the NLRP3 inflammasome in the FLS was also increased after short-term treatment $(6 \mathrm{~h})$ and long-term treatment $(48 \mathrm{~h})$ with MSU. Our findings collectively provide a new insight into the role of synovial fibroblasts in the pathophysiology of gout. They suggest that synovial fibroblasts may participate in the secretion of IL-1 $\beta$ via NLRP3 inflammasome formation, which could make synovial fibroblasts a potential therapeutic target for gout.

In rheumatoid arthritis (RA), synovial fibroblasts play an important role in the process of cartilage and bone erosion, presumably via the synthesis of inflammatory mediators, including chemokines [28,29], matrix metalloproteinases (MMPs) [30], and cytokines [31]. Peng et al. recently showed that MSU crystals upregulated cyclooxygenase 2 (COX-2) and interleukin 8 (IL-8) gene expression in human synovial fibroblasts [32]. Also in RA, elevated levels of miR-203 led to increased secretion of MMP-1 and IL-6 via the NF- $\mathrm{kB}$ pathway and thereby contributed to the activated phenotype of synovial fibroblasts [33]. In cultures of synovial cells from patients with RA, blocking TNF- $\alpha$ with antibodies significantly reduced the production of IL-1 $\beta$, IL-6 and IL-8 [34].
Chen et al. showed that MSU, alone or in combination with TNF- $\alpha$ or IL-1 $\beta$, were able to significantly increase the release of the IL- 6 , the chemokine CXCL8 and MMP-1 on the activation of human FLS from RA patients and normal control subjects [35]. Although this is an interesting study, they did not detect the release of IL-1 $\beta$, by which was did in our present study. In summary, these studies suggest a potential role for synovial fibroblasts in MSU-induced inflammation. Our present study demonstrated that MSU induced a transient increase in the secretion of IL-1 $\beta$, which indicates a potential role for FLS in the inflammatory pathophysiology of gout. However, no increase of IL-6 and TNF-a was detected in synovial fibroblasts after exposure to MSU. This may suggest that FLS play a different role in MSU triggered inflammation compared to macrophages and other types of immune cells. More studies are needed to further elucidate the mechanisms.

The concentration of MSU in our study ranged from 1 $\mathrm{ug} / \mathrm{ml}$ to $500 \mathrm{ug} / \mathrm{ml}$. It was lower than that used in other in vitro studies using macrophages or monocytes [36-38]. $50 \mathrm{ug} / \mathrm{ml}$ of MSU only induced mature IL-1 $\beta$ secretion from FLS at the $6 \mathrm{~h}$ time point, which suggests that the effect of MSU on FLS is transient. Our results are supported by Margalit et al. [39], who showed that prostaglandins and other arachidonic acid metabolites, the inflammation mediation, are transiently formed after MSU crystal injection with peak levels occurring shortly after treatment. In the clinic, crystals are present, and may be retrieved by aspirating the synovial fluid (SF) of gout patients, during gout flares, but also during asymptomatic periods $[40,41]$. However, no correlation has been reported between the size, shape and numbers of crystals in the SF and the severity of inflammation [42]. A potential explanation for this may be that the relationship between crystal formation and inflammation is modified by individual genomic background. Further analysis of the factors that regulate the cellular response to inflammatory crystals may identify potential therapeutic targets for gout.

IL-1 $\beta$ is a well-known member of the IL- 1 family and a highly inflammatory cytokine. The production and activity of IL-1 $\beta$ is tightly regulated in a multi-step process. IL-1 $\beta$ mRNA transcripts are rapidly expressed, and the precursor of IL- $1 \beta$ is synthesized based on the activation of Toll-like receptors (TLRs) or IL-1 signaling [43]. Our study shows that mRNA levels of IL- $1 \beta$ are consistent with pro-IL-1 $\beta$ protein expression in FLS exposed to MSU. In vitro studies in human monocytes demonstrate that the phagocytosis of MSU crystals induces the release of several cytokines, including IL- $1 \beta$, TNF- $\alpha$, IL-8, and IL-6 [44,45]. Based on in vitro studies and in vivo animal models, gout has been identified as a prototypical IL-1 $\beta$-dependent disease, an observation that has also 


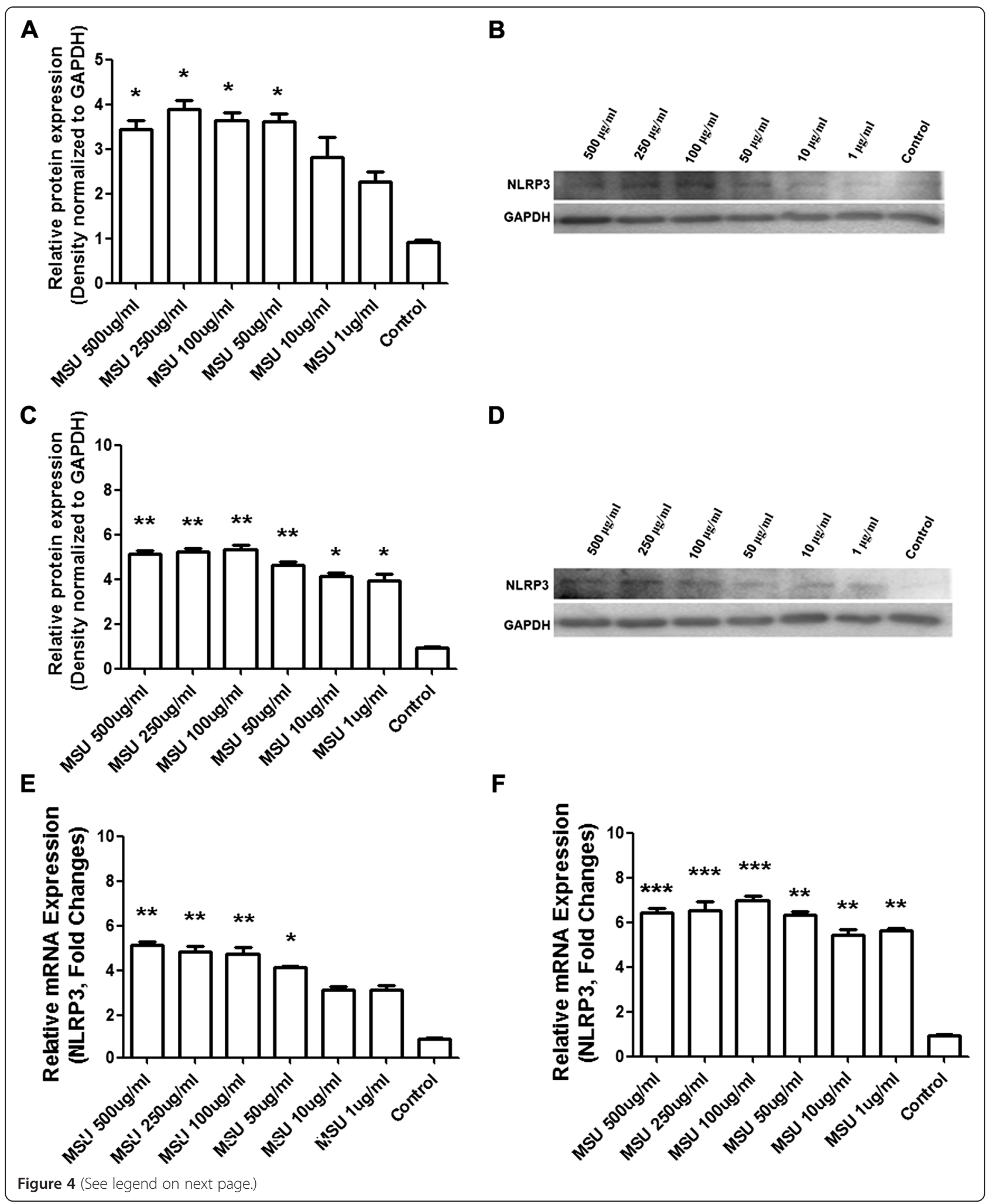


(See figure on previous page.)

Figure 4 Changes of NLRP3 protein level detected by Western blot and mRNA level detected by Q-PCR in the FLS. FLS were stimulated with $1 \mathrm{ug} / \mathrm{ml}, 10 \mathrm{ug} / \mathrm{ml}, 50 \mathrm{ug} / \mathrm{ml}, 100 \mathrm{ug} / \mathrm{ml}, 250 \mathrm{ug} / \mathrm{ml}$ and $500 \mathrm{ug} / \mathrm{ml}$ of MSU at short-term time point $6 \mathrm{~h}$ and long-term time point $48 \mathrm{~h}$ respectively. Western blot analysis detected the NLPRP3 protein levels in different groups were expressed as a ratio to that of corresponding GAPDH at the $6 \mathrm{~h}$ time point (A). The expected size protein band of NLPRP3 was shown at the $6 \mathrm{~h}$ time point (B). At the $48 \mathrm{~h}$ time point, the NLPRP3 protein levels in different groups were expressed as a ratio to that of corresponding GAPDH (C). The expected size protein band of NLPRP3 was shown at the $48 \mathrm{~h}$ time point (D). There was significant difference for the levels of NLRP3 mRNA expression in the cells of FLS exposed to $50 \mathrm{ug} / \mathrm{ml}, 100 \mathrm{ug} / \mathrm{ml}, 250 \mathrm{ug} / \mathrm{ml}$ and $500 \mathrm{ug} / \mathrm{ml}$ concentration MSU at the $6 \mathrm{~h}$ time course (E). The dramatically increase for the NLRP3 mRNA levels in the cells of FLS exposed to all concentration MSU at the $48 \mathrm{~h}$ time course were detected (F). Data presented are mean \pm S.E.M. Data are three independent experiments. ${ }^{*}$ represents $P<0.05$, ${ }^{* *}$ represents $P<0.01$ and ${ }^{* * *}$ represents $P<0.001$ in comparison with control during statistical analysis.

been confirmed by clinical studies, addressing the therapeutic effect of IL-1 blockage $[8,46]$. In addition, the current study suggests that the release of $\mathrm{IL}-1 \beta$ by synovial fibroblasts also may be of importance in the pathophysiology of gout.

Pro-IL- $1 \beta$ needs a second signal in order to maturate its active form, since pro- IL- $1 \beta$ is biologically inactive and its processing to the active, secreted form takes places inside the cytoplasm or in specialized secretory lysosomes [47]. NLRP3 and its adaptor protein, ASC, mediate caspase 1-dependent processing of certain cytokines, especially IL-1 $\beta[48,49]$. There is clear evidence that MSU crystals trigger the activation of the NLRP3/ ASC/caspase1 inflammasome, an effect that culminates in the production of IL-1 $\beta[17,50,51]$. The present study showed increased mRNA and protein levels of NLRP3 in FLS exposed to MSU, which suggests that IL-1 $\beta$ secretion is regulated by the NLRP3 inflammasome in FLS.

It is well-known that the release of biologically active IL-1 $\beta$ needs two signals, which means the production of mature IL- $1 \beta$ is tightly regulated. On the one hand, transcription of the IL-1 $\beta$ gene and production of cytosolic pro-IL-1 $\beta$ are dependent on activation of NF- $k B$ via, for example, TLRs. On the other hand, the second signal leads to cleavage of pro-IL- $1 \beta$ by NLRP3/ASC/caspase1 and release of mature IL-1 $\beta$ [52-54]. The present study showed a transient increase in IL-1 $\beta$ and NLPR3 expression in FLS. Collectively, our data suggests that cleavage of pro- IL- $1 \beta$ to IL- $1 \beta$ is induced by the NLRP3 inflammasome. Migita et al. showed that MSU stimulation resulted in the activation of caspase- 1 and production of active IL- $1 \beta$ and IL- $1 \alpha$ in serum amyloid A (SAA)primed synovial fibroblasts, and that the effect could be impaired in cells by silencing NLRP3 using siRNA or inhibition of caspase-1 [55]. Together with the results of the current study, these findings provide insight into the molecular processes underlying the synovial inflammatory condition of gout.

In addition, our present results showed that, even though the NLRP3 expression were upregulated throughout the whole range of concentrations and time points used, the most effects of MSU are only observed at $50 \mathrm{ug} / \mathrm{mL}$ of $6 \mathrm{~h}$ time points, which is essentially in agreement with pro-IL-1 $\beta$ expression in the FLS cells. Recently, Choi and Ryter [56] summarized how the NLRP3 inflammasome is typically activated by the bimodal signaling pathway. A Toll-like receptor (TLR)-dependent priming step activates the NF-kB dependent transcription of NLRP3 and the pro-forms of the pro-inflammatory cytokines (i.e., IL-1 $\beta$ ). The activation of the P2X7R receptor by stimulation with exogenous ATP, which triggers potassium ion $(\mathrm{K}+)$ efflux, is the second signal. Besides that, the NLRP3 inflammsome may be activated by agents that cause mitochondrial dysfunction and the particulates such as monosodium urate or silica. Based on these possible reasons, although the most effects of MSU are only observed at $50 \mathrm{ug} / \mathrm{mL}$ of $6 \mathrm{~h}$ time points, the NLRP3 expression in our present study may be existed throughout the whole range of concentrations and time points we used. It is currently unclear how the results of relatively short term expression in the FLS relate to IL-1 $\beta$ and pro-IL-1 $\beta$ levels in a condition characterised by continuing MSU exposure during gout.

\section{Conclusions}

To our knowledge, the current study is the first to demonstrate the essential role of the NLRP3 inflammasome in synovial fibroblasts in the pathogenesis of gout. MSU activated the NLRP3 inflammasome in FLS, which led to the processing and maturation of pro-IL- $1 \beta$ into the active form of IL-1 $\beta$. MSU-induced production of IL-I $\beta$ was transient and partially dependent on NLRP3 inflammasome activation. It is hypothesized that a transient increase in IL-1 $\beta$ production may enhance inflammation and then transfer the inflammatory reaction to other cells. The results indicate that targeting the NLRP3 inflammasome in FLS may be a relevant therapeutic strategy in the treatment of gout.

\section{Additional file}

Additional file 1: Figure S1. MSU induced IL-1 $\beta$ production in FLS. FLS were stimulated with $10 \mathrm{ug} / \mathrm{ml}, 25 \mathrm{ug} / \mathrm{ml}, 50 \mathrm{ug} / \mathrm{ml}, 75 \mathrm{ug} / \mathrm{ml}$ and $100 \mathrm{ug} / \mathrm{ml}$ of MSU at $6 \mathrm{~h}$ and $48 \mathrm{~h}$ respectively. The control group is treated with PBS, which is used to dilute different dosage of MSU. Supernatants were detected for IL-1 $1 \beta$ protein by ELISA. The concentration of MSU $50 \mathrm{ug} / \mathrm{ml}$ induced the 
significant increase of IL-1 $\beta$ in the supernatants collected after 6 hours MSU exposure $(A, p<0.05)$. There is no significant difference at the $48 \mathrm{~h}$ time point (B). Data presented are mean \pm S.E.M. * *epresents $\mathrm{P}<0.05$ in comparison with control during statistical analysis.

\section{Abbreviations}

MSU: Monosodium urate; IL-1B: Interleukin-1 B; FLS: Fibroblast-like synoviocytes; NLRP3: Nucleotide-binding domain-like receptor protein 3; ASC: Apoptosis-associated speck like protein; MCP-1: Monocyte chemoattractant protein-1; RA: Rheumatoid arthritis; MMPs: Matrix metalloproteinases; COX-2: Cyclooxygenase 2; TLRs: Toll-like receptors: SAA: Serum amyloid A.

\section{Competing interests}

The authors declare that they have no competing interests.

\section{Authors' contributions}

Conceived and designed the experiments: HJZ, JHQ and QL. Performed the experiments: SCZ, XXZ, YX, LHZ and QL. Analyzed the data: HJZ, JHQ and QL. Contributed reagents/materials/analysis tools: SCZ, XXZ, YX, LHZ and QL. Wrote the paper: JHQ and QL. ${ }^{\dagger} \mathrm{SCZ}$ and XXZ contributed equally. All the authors have read and approved the final manuscript.

\section{Acknowledgements}

This study was supported by Major Project of Shanghai Science and Technology Foundation (NO.11DJ1400101) and National Natural Science Foundation of China (NO. 31371083, 81302573 and 81100943).

\section{Author details}

'Division of Rheumatology, Huashan Hospital, Fudan University, Shanghai, China. ${ }^{2}$ Institute of Rheumatology, Immunology and Allergy, Fudan University, Shanghai, China. ${ }^{3}$ Department of Anatomy, Histology and Embryology, Shanghai Medical College of Fudan University, 138 Yixueyuan Road, Shanghai 200032, PR China. ${ }^{4}$ Division of Emergency Medicine, Boston Children's Hospital, Harvard Medical School, Boston, MA, USA. ${ }^{5}$ Key Laboratory of Medical Imaging Computing and Computer Assisted Intervention of Shanghai, 138 Yixueyuan Road, Shanghai 200032, PR China.

\section{Received: 29 April 2014 Accepted: 12 March 2015}

\section{Published online: 10 April 2015}

\section{References}

1. Doherty M. New insights into the epidemiology of gout. Rheumatology (Oxford). 2009;48(2):ii2-8.

2. Schiltz C, Lioté F, Prudhommeaux F, Meunier A, Champy R, Callebert J, et al. Monosodium urate monohydrate crystal-induced inflammation in vivo: quantitative histomorphometric analysis of cellular events. Arthritis Rheum. 2002;46(6):1643-50.

3. Kingsbury SR, Conaghan PG, McDermott MF. The role of the NLRP3 inflammasome in gout. J Inflamm Res. 2011;4:39-49.

4. Rock KL, Kataoka H, Lai JJ. Uric acid as a danger signal in gout and its comorbidities. Nat Rev Rheumatol. 2013;9(1):13-23.

5. Dalbeth N, Haskard DO. Mechanisms of inflammation in gout. Rheumatology (Oxford). 2005;44(9):1090-6.

6. Punzi L, Scanu A, Ramonda R, Oliviero F. Gout as autoinflammatory disease: new mechanisms for more appropriated treatment targets. Autoimmun Rev. 2012;12(1):66-71.

7. Gonzalez EB. An update on the pathology and clinical management of gouty arthritis. Clin Rheumatol. 2012;31(1):13-21.

8. Mitroulis I, Skendros P, Ritis K. Targeting IL-1beta in disease; the expanding role of NLRP3 inflammasome. Eur J Intern Med. 2010;21(3):157-63.

9. Dinarello CA. How interleukin-1 $\beta$ induces gouty arthritis. Arthritis Rheum. 2010;62(11):3140-4.

10. Ferraccioli G, Bracci-Laudiero L, Alivernini S, Gremese E, Tolusso B, De Benedetti F. Interleukin- $1 \beta$ and interleukin- 6 in arthritis animal models: roles in the early phase of transition from acute to chronic inflammation and relevance for human rheumatoid arthritis. Mol Med. 2010;16(11-12):552-7.

11. Ghiringhelli F, Apetoh L, Tesniere A, Aymeric L, Ma Y, Ortiz C, et al. Activation of the NLRP3 inflammasome in dendritic cells induces IL-1 beta-dependent adaptive immunity against tumors. Nat Med. 2009;15(10):1170-8.
12. Martinon F, Mayor A, Tschopp J. The inflammasomes: guardians of the body. Annu Rev Immunol. 2009;27:229-65.

13. Sheedy FJ, Grebe A, Rayner KJ, Kalantari P, Ramkhelawon B, Carpenter SB, et al. CD36 coordinates NLRP3 inflammasome activation by facilitating intracellular nucleation of soluble ligands into particulate ligands in sterile inflammation. Nat Immunol. 2013;14(8):812-20.

14. Freudweiler M. Study of the nature of gouty tophi. Dtsch Arch Klin Med. 1899;63:36-41.

15. McGettrick AF, O'Neill LA. NLRP3 and IL-1 $\beta$ in macrophages as critical regulators of metabolic diseases. Diabetes Obes Metab. 2013;15(3):19-25.

16. Murakami Y, Akahoshi T, Hayashi I, Endo H, Kawai S, Inoue M, et al. Induction of triggering receptor expressed on myeloid cells 1 in murine resident peritoneal macrophages by monosodium urate monohydrate crystals. Arthritis Rheum. 2006;54(2):455-62.

17. Martinon F, Pétrilli V, Mayor A, Tardivel A, Tschopp J. Gout-associated uric acid crystals activate the NALP3 inflammasome. Nature. 2006;440(7081):237-41.

18. Martin WJ, Walton M, Harper J. Resident macrophages initiating and driving inflammation in a monosodium urate monohydrate crystal-induced murine peritoneal model of acute gout. Arthritis Rheum. 2009;60(1):281-9.

19. Amaral FA, Costa W, Tavares LD, Sachs D, Coelho FM, Fagundes CT, et al. NLRP3 inflammasome-mediated neutrophil recruitment and hypernociception depend on leukotriene B(4) in a murine model of gout. Arthritis Rheum. 2012;64(2):474-84.

20. Scanu A, Oliviero F, Gruaz L, Sfriso P, Pozzuoli A, Frezzato F, et al. High-density lipoproteins downregulate CCL2 production in human fibroblast-like synoviocytes stimulated by urate crystals. Arthritis Res Ther. 2010;12(1):R23.

21. Wijbrandts CA, Van Leuven SI, Boom HD, Gerlag DM, Stroes EG, Kastelein JJ, et al. Sustained changes in lipid profile and macrophage migration inhibitory factor levels after anti-tumour necrosis factor therapy in rheumatoid arthritis. Ann Rheum Dis. 2009;68(8):1316-21.

22. Landis RC, Haskard DO. Pathogenesis of crystal-induced inflammation. Curr Rheumatol Rep. 2001;3(1):36-41.

23. Mitroulis I, Kambas K, Ritis K. Neutrophils, IL-1 $\beta$, and gout: is there a link? Semin Immunopathol. 2013;35(4):501-12.

24. Mankan AK, Dau T, Jenne D, Hornung V. The NLRP3/ASC/Caspase-1 axis regulates IL-1 $\beta$ processing in neutrophils. Eur J Immunol. 2012;42(3):710-5.

25. Guarda G, Dostert C, Staehli F, Cabalzar K, Castillo R, Tardivel A, et al. T cells dampen innate immune responses through inhibition of NLRP1 and NLRP3 inflammasomes. Nature 9. 2009;460(7252):269-73.

26. Dalbeth N, Fransen J, Jansen TL, Neogi T, Schumacher HR, Taylor WJ. New classification criteria for gout: a framework for progress. Rheumatology (Oxford). 2013;52(10):1748-53.

27. Neogi T. Clinical practice. Gout N Engl J Med 3. 2011;364(5):443-52.

28. Perper SJ, Browning B, Burkly LC, Weng S, Gao C, Giza K, et al. TWEAK is a novel arthritogenic mediator. J Immunol 15. 2006;177(4):2610-20.

29. Chang SK, Noss EH, Chen M, Gu Z, Townsend K, Grenha R, et al. Cadherin-11 regulates fibroblast inflammation. Proc Natl Acad Sci U S A. 2011;108(20):8402-7.

30. Thwin MM, Douni E, Arjunan P, Kollias G, Kumar PV, Gopalakrishnakone P. Suppressive effect of secretory phospholipase A2 inhibitory peptide on interleukin-1beta-induced matrix metalloproteinase production in rheumatoid synovial fibroblasts, and its antiarthritic activity in hTNFtg mice. Arthritis Res Ther. 2009;11(5):R138.

31. Gravallese EM. Bone destruction in arthritis. Ann Rheum Dis. 2002;61(2):ii84-6.

32. Peng YJ, Lee CH, Wang CC, Salter DM, Lee HS. Pycnogenol attenuates the inflammatory and nitrosative stress on joint inflammation induced by urate crystals. Free Radic Biol Med. 2012;52(4):765-74.

33. Stanczyk J, Ospelt C, Karouzakis E, Filer A, Raza K, Kolling C, et al. Altered expression of microRNA-203 in rheumatoid arthritis synovial fibroblasts and its role in fibroblast activation. Arthritis Rheum. 2011;63(2):373-81.

34. Oussirot E, Streit G, Wendling D. Infectious complications with anti-TNFalpha therapy in rheumatic diseases: a review. Recent Pat Inflamm Allergy Drug Discov. 2007;1(1):39-47.

35. Da Chen P, Wong CK, Tam LS, Li EK, Lam CW. Activation of human fibroblast-like synoviocytes by uric acid crystals in rheumatoid arthritis. Cell Mol Immunol. 2011;8(6):469-78.

36. Scott P, Ma H, Viriyakosol S, Terkeltaub R, Liu-Bryan R. Engagement of CD14 mediates the inflammatory potential of monosodium urate crystals. J Immunol. 2006;177(9):6370-8. 
37. Yao X, Ding Z, Xia Y, Wei Z, Luo Y, Feleder C, et al. Inhibition of monosodium urate crystal-induced inflammation by scopoletin and underlying mechanisms. Int Immunopharmacol. 2012;14(4):454-62.

38. Mylona EE, Mouktaroudi M, Crisan TO, Makri S, Pistiki A, Georgitsi M, et al. Enhanced interleukin-1 $\beta$ production of PBMCs from patients with gout after stimulation with Toll-like receptor-2 ligands and urate crystals. Arthritis Res Ther. 2012;4(4):R158.

39. Margalit A, Duffin KL, Shaffer AF, Gregory SA, Isakson PC. Altered arachidonic acid metabolism in urate crystal induced inflammation. Inflammation. 1997;21(2):205-22.

40. Pascual E, Batlle-Gualda E, Martínez A, Rosas J, Vela P. Synovial fluid analysis for diagnosis of intercritical gout. Ann Intern Med. 1999;131(10):756-9.

41. Antommattei $\mathrm{O}$, Schumacher HR, Reginato AJ, Clayburne G. Prospective study of morphology and phagocytosis of synovial fluid monosodium urate crystals in gouty arthritis. J Rheumatol. 1984;11(6):741-4.

42. Perez-Ruiz F. Treating to target: a strategy to cure gout. Rheumatology (Oxford). 2009;48(2):ii9-14.

43. Virtue A, Wang $H$, Yang XF. MicroRNAs and toll-like receptor/interleukin-1 receptor signaling. J Hematol Oncol. 2012;5:66

44. Duff GW, Atkins E, Malawista SE. The fever of gout: urate crystals activate endogenous pyrogen production from human and rabbit mononuclear phagocytes. Trans Assoc Am Physicians. 1983;96:234-45.

45. Di Giovine FS, Malawista SE, Thornton E, Duff GW. Urate crystals stimulate production of tumor necrosis factor alpha from human blood monocytes and synovial cells. Cytokine mRNA and protein kinetics, and cellular distribution. J Clin Invest. 1991;7(4):1375-81.

46. Masters SL, Simon A, Aksentijevich I, Kastner DL. Horror autoinflammaticus: the molecular pathophysiology of autoinflammatory disease $\left(^{*}\right)$. Annu Rev Immunol. 2009;27:621-68.

47. Dinarello CA. Immunological and inflammatory functions of the interleukin-1 family. Annu Rev Immunol. 2009;27:519-50.

48. Agostini L, Martinon F, Burns K, McDermott MF, Hawkins PN, Tschopp J. NALP3 forms an IL-1 beta-processing inflammasome with increased activity in Muckle-Wells autoinflammatory disorder. Immunity. 2004;20(3):319-25.

49. Martinon F, Agostini L, Meylan E, Tschopp J. Identification of bacterial muramyl dipeptide as activator of the NALP3/cryopyrin inflammasome. Curr Biol. 2004;14(21):1929-34.

50. Giamarellos-Bourboulis EJ, Mouktaroudi M, Bodar E, Van der Ven J, Kullberg BJ, Netea MG, et al. Crystals of monosodium urate monohydrate enhance lipopolysaccharide-induced release of interleukin 1 beta by mononuclear cells through a caspase 1-mediated process. Ann Rheum Dis. 2009;68(2):273-8.

51. Hoffman HM, Scott P, Mueller JL, Misaghi A, Stevens S, Yancopoulos GD, et al. Role of the leucine-rich repeat domain of cryopyrin/NALP3 in monosodium urate crystal-induced inflammation in mice. Arthritis Rheum. 2010;62(7):2170-9.

52. Schroder K, Tschopp J. The inflammasomes. Cell. 2010;140(6):821-32.

53. Van de Veerdonk FL, Netea MG, Dinarello CA, Joosten LA. Inflammasome activation and IL-1 $\beta$ and $I L-18$ processing during infection. Trends Immunol. 2011;32(3):110-6.

54. Chen GY, Nuñez G. Sterile inflammation: sensing and reacting to damage. Nat Rev Immunol. 2010;10(12):826-37.

55. Migita K, Koga T, Satomura K, Izumi M, Torigoshi T, Maeda Y, et al. Serum amyloid $A$ triggers the mosodium urate -mediated mature interleukin-1 $\beta$ production from human synovial fibroblasts. Arthritis Res Ther. 2012;14(3):R119.

56. Choi AJ, Ryter SW. Inflammasomes: molecular regulation and implications for metabolic and cognitive diseases. Mol Cells. 2014;37(6):441-8.

\section{Submit your next manuscript to BioMed Central and take full advantage of:}

- Convenient online submission

- Thorough peer review

- No space constraints or color figure charges

- Immediate publication on acceptance

- Inclusion in PubMed, CAS, Scopus and Google Scholar

- Research which is freely available for redistribution 